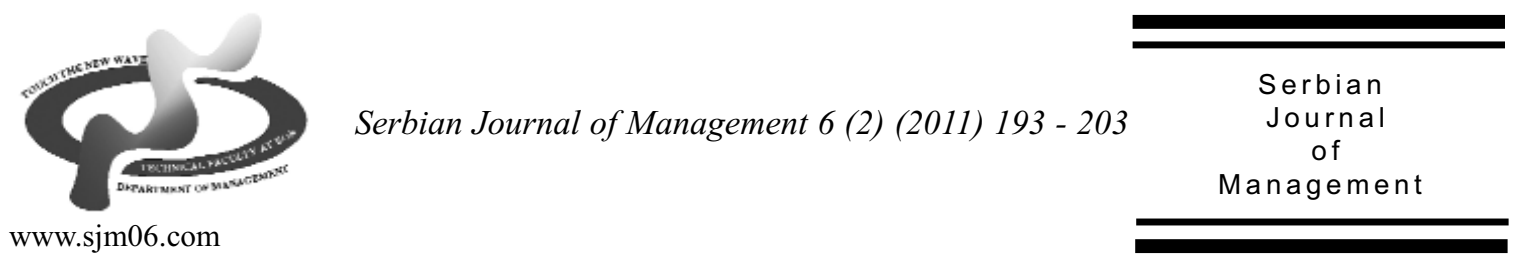

\title{
LOCUS OF CONTROL AND JOB SATISFACTION: PSU EMPLOYEES
}

\author{
Lakshman Vijayashree ${ }^{a^{*}}$ and Mali Vishalkumar Jagdischchandrab \\ $a_{P E S}$ School of Engineering, \\ Hosur Road, Bangalore- 100, India

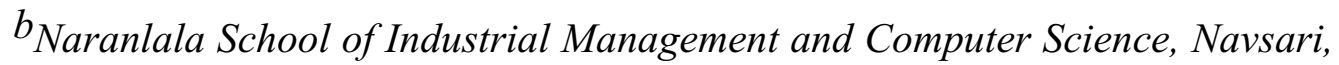 \\ Bhagwati Sankul, Near Eru Char Rasta, Navsari-396450, Gujarat, India
}

(Received 26 September 2010; accepted 12 May 2011)

\begin{abstract}
Previous research studies have demonstrated that internal/external locus of control impacts job satisfaction. The present study thus aims to analyze type of locus of control and its relation with job satisfaction. The study will be of great help for organization to understand and know what type of locus of control their employees has and how it has an impact on job satisfaction.

The objectives of this study were: 1- To identify the type of Locus of Control (i.e. Internal or External) present in Public Sector Units (PSU) in Bangalore and 2- To analyze the impact of different type of Locus of Control on job satisfaction of PSU Employees. Further hypothesis was also set to check the relationship between locus of control and job satisfaction. In addition, the relationship between different demographic factors was also examined. The tool used for this study was Loco Inventory. The concept of locus of control by Levenson (1972) was used to develop Loco Inventory (Locus of Control in Organization Inventory). The survey used a questionnaire, which had thirty five statements which highlights the factors that determine the locus of control and job satisfaction level of the employees. The Ratio, ANOVA, and Correlation analysis were used as statistical techniques for analysis.

The results indicate that there is a positive correlation between internal locus of control and job satisfaction as well as between External (other) locus of control and job satisfaction. And in case of External (Chance) locus of control and job satisfaction there exists partial positive correlation. As per this study Job satisfaction level among the employees is also good as the mean is 17 , which is closer to maximum scale value of 25 . As per ANOVA table there is a significant variance between internality and age as well as between externality (chance) and age. There is no significant relationship between internality and demographic factors like gender and education. There is no significant relationship between externality (others) and demographic factors like gender, age and education. There is no significant relationship between externality (chance) and demographic factors like gender and education.
\end{abstract}

Keywords: Internal-external locus of control, Job Satisfaction, Loco Inventory

\footnotetext{
* Corresponding author: vijayashree.dsi@gmail.com
}

DOI: $10.5937 /$ sjm 1102193V 


\section{INTRODUCTION}

Locus of control is a term in psychology that refers to a person's belief about what causes the good or bad results in his life, either in general or in a specific area such as health or academics. It also refers to an individual's generalized expectations concerning where control over subsequent events resides. In other words, who or what is responsible for what happens. Locus of control formulation classifies the generalized beliefs, concerning who or what influences things along a bipolar dimension from internal to external control: "Internal control" is the term used to describe the belief that control of future outcomes resides primarily in oneself while "external control" refers to the expectancy that control is outside of oneself, either in the hands of powerful other people or due to fate/chance. Rotter's conceptualization viewed locus of control as one-dimensional (internal to external) and Levenson's model asserts that there are three independent dimensions: Internality, Chance, and Powerful Others. According to Levenson's model, one can endorse each of these dimensions of locus of control independently and at the same time. For example, A person might simultaneously believe that both oneself and powerful others influence outcomes, but that chance does not.

From the time of Introduction, the locus of control construct has undergone considerable elaboration and several contextspecific instruments have been developed. Those with a high internal locus of control have better control of their behavior, tend to exhibit more achievement orientation, and are more likely to attempt to influence other people than those with a high external locus of control. Those with a high internal locus of control are more likely to assume that their efforts will be successful. They are more active in seeking information and knowledge concerning their situation. Generally, the development of locus of control stems from family, culture, and past experiences leading to rewards. Most internals have been shown to come from families that focused on effort, education, and responsibility. On the other hand, most externals come from families of a low socioeconomic status where there is a lack of life control. Psychological research has found that people with a more internal locus of control seem to be better off, e.g., they tend to be more achievement oriented and to get better paid jobs. Sometimes Locus of Control is seen as a stable, underlying personality construct, but this may be misleading, since the theory and research indicates that that locus of control is largely learned.

Loco inventory is an instrument to measure locus of control. Loco inventory has been developed for use in organizations. The locus of control orientation are reflected in the way people feel about what happens in the organization and how much control they, other significant persons, or neither (being a matter of luck), have in important organizational matters. These matters relate to success or effectiveness, influence, acceptability, career, advancement and rewards. Levenson has divided the concept of Locus of control in mainly two parts i.e. External and Internal, in external there are again two parts i.e. Chance or luck and other external factors.

Since most of the working hours are spent at work, it is imperative to find out the various factors that determine job happiness. Evidently, it is all about the gap between reality and expectations, but the issue seems 
to be much more complicated than it appears. According to many researchers the type of locus of control an individual carries has an effect on the level of job satisfaction. Job satisfaction has been defined as a pleasurable emotional state resulting from the appraisal of one's job; an affective reaction to one's job; and an attitude towards one's job. Weiss (2002) has argued that job satisfaction is an attitude but points out that researchers should clearly distinguish the objects of cognitive evaluation which are affect (emotion), beliefs and behaviors. This definition suggests that we form attitudes towards our jobs by taking into account our feelings, our beliefs, and our behaviors.

Some argue that Maslow's hierarchy of needs theory, a motivation theory, laid the foundation for job satisfaction theory. This theory explains that people seek to satisfy five specific needs in life physiological needs, safety needs, social needs, self-esteem needs, and self-actualization (Rani and Selvarani, 2011). Here for this study five factors were taken into consideration: type of work, co-workers, pay, supervisor and promotion.

\section{REVIEW OF LITERATURE}

Levenson (1972) used the concept of locus of control to develop Loco Inventory (Locus of Control in Organization Inventory). Levenson (1972) distinguished between two types of external locus of control: significant others and chance or luck.

Julian B. Rotter (1954) says that people with an internal locus of control are more likel to: be attentive to opportunities in the environment to improve the attainment of their goals, engage in actions to improve their environment, place a greater emphasis on striving for achievement, and be more inclined to develop their own skills.

Bachrach \& Peterson (1976) \& Lefcourt (1982) say that the development of locus of control is hypothesized to progress from a more external locus of control to a more internal locus of control as one matures.

Cummins (1989) examined the relationship between social support and locus of control in determining job satisfaction levels and stress. Those with an internal locus of control developed ways to shield stress while those with an external locus of control relied on supervisory support to reduce stress. Individuals with an internal locus of control were shown to be more satisfied with their jobs regardless of stress levels while those with an external locus of control tended to be less satisfied with their jobs due to stress.

Sandstrom \& Coie (1999) says that External locus of control is correlated with peer rejection. Oesterman et al (1999) says that External locus of control is correlated with aggression.

Halloran, Doumas, John, \& Margolin (1999) found that Individuals expressing a more internal locus of control believe that their behavior is directly related to the outcomes because they have control over their environment.

Leone \& Burns (2000) says that Locus of control is a construct that measures the degree to which individuals believe they are responsible for the consequences of their behavior.

Judge, Timothy; Bono, Joyce(2001) found that there is a positive correlation (of 0.32 ) between internal locus of control and job satisfaction.

John Salazar, Susan Hubbard \& Leta Salazar (2002) found that internal/external locus of control impacts job satisfaction. 
Additionally, research indicates that locus of control relates to many other work-related perceptions.

Stella Flytzani \& Peter Nijkamp report that managers with the internal locus of control are more successful in coping with difficulties inherent in adjusting to a foreign culture.

Hsu-I Huang (2006) exhibited that male culinary arts workers had a higher degree of internal locus of control than female culinary arts workers. Internal locus of control was significantly and positively correlated with employee job satisfaction.

Heidi A. Nerison (1999) reports that in order to prevent job dissatisfaction and retain employees, employers need to keep up with changing values related toward work. It is important to stay in tune with current employee values.

Richard A. Murray (1999) felt that promotion, pay increases the feel good factor in a person which indirectly increases the satisfaction level in an individual.

Richard (1999); Kuye and Sulaimon (2011) felt that team work increases job satisfaction. They also said that team work has got negative correlation with benefits package and has positive correlation with overall satisfaction of the job.

Morris (1981) defined job satisfaction as an employee's affect response to various aspects of his work environment. Employees that are satisfied and happy in with their jobs are more dedicated to doing a good job and taking care of customers that sustain the operation.

\section{THEORETICAL FRAMEWORK \\ 3.1 Operational Definition for the factors of Locus of Control:}

- Internal Locus of Control: Individuals with a high internal locus of control believe that events result primarily from their own behavior and actions.

- External Locus of Control: Individuals with high external locus of control (chance or others) believe that powerful others, fate, or chance primarily determine events (Fig. $1)$.

\section{OBJECTIVES}

- To identify the type of Locus of Control (i.e. Internal or External) present in employees of public sectors in Bangalore.

- To identify the relationship between Locus of Control on job satisfaction.

\section{HYPOTHESES OF THE STUDY}

The following are the list of Hypothesis Statements.

- There is a positive correlation between Internal Locus of Control and Job satisfaction among the employees of public sectors in Bangalore.

\section{METHODOLOGY}

The study required both primary and secondary data. The primary data was collected with the help of a survey conducted in Bangalore. The main concentration to collect the required data was from the employees of 5 public sector companies. Data for the study was obtained by using the structured questionnaire.

The questionnaires were distributed to 100 employees of various public sector companies. Five major companies were taken into consideration and from each outlet 20 employees were given the questionnaire. But at the end the researcher has got only 73 questionnaires out of 100 given to the 
employees. The secondary data for literature review was collected from EBSCO database, Google Website and other journal research papers.

\subsection{Formulation of Questionnaire}

The survey used a questionnaire, which had thirty five statements which highlights the factors that determine the type of locus of control and job satisfaction level of the employees. The responses were collected on a Five Point Likert Scale ranging from 1 (Strongly Disagree) to 5(Strongly Agree).

The ratio analysis, correlation analysis, Regression analysis and ANOVA one-way were used as statistical tool for analysis.

\section{RESULTS OF ANALYSIS}

In this research work demographic variable such as gender, marital status, age, educational qualification and experience was used.

As number of female was less in public sector, questionnaire was distributed among both genders but $79.5 \%$ in male and $20.5 \%$ in female returned the filled up questionnaire. Results of demographic analysis are presented in Tables 1,2 and 3.

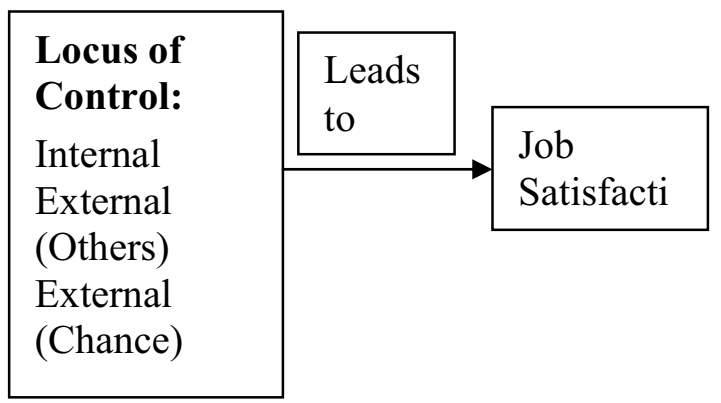

Figure 1. Factors of Locus

\subsection{Analysis for the objective 1:}

The aim is to identify the type of Locus of Control (Internal or External) present among the employees of public sectors in Bangalore.

\subsubsection{Ratio Analysis}

In this research work, the ratio analysis was used to find out the type of locus of control present in the employees. Totally three ratios were calculated, they were (1) Internality/E-O, (2) Internality/E-C and (3) Internality/Total-E. The answers of these 3 ratios were $1.07,1.13$ and 0.55 respectively. And as out of three answers two answer is more than 1, we can say that there is a good amount of internal locus of control exists among the employees of public sector in Bangalore.

\subsubsection{Mean}

Mean was also used to identify the type of locus of control present in the employees. After analyzing the data it was found that most of the employees from sample of 73 belong to internality with the highest mean of 35.26. As the mean of internality is higher than other two dimensions i.e. Externality (chance) and Externality (Others) we can say that most of the public sector employees have internal locus of Control. After internality second dimension is Externality (Others) with the mean of 32.93. Externality (Chance) stood last with the mean of 31.30.

Mean for job satisfaction level of employees was also founded. Scale for Job Satisfaction was taken as 1 to 25 with five questions on job satisfaction. After analyzing the data it was found that the mean for Job Satisfaction is 17 which is closer to 
maximum value 25 so, we can say that employees of PSUs have good level of Job Satisfaction.

\subsection{Analysis for objective 2:}

The aim is to analyze the impact of type of Locus of Control on job satisfaction.

\subsubsection{Correlation}

While the correlation could range between -1.0 and +1.0 , we need to know if any correlation found between two variables is significant or not (i.e., if it has occurred solely by chance or if there is a high probability of its existence). A significance of $p=.05$ is the generally accepted conventional level. This indicates that 95 times out of 100 , we can be sure that there is a true or significant correlation between the two variables, and there is only a $5 \%$ chance that the relationship does not truly exist. We would not know which variable causes what, but we know that the two variables are associated with each other. Thus the hypothesis postulates a significant positive (or negative) relationship between the two. The results of the findings are as following

Table 1. Demographic variable-Gender

\begin{tabular}{|l|l|l|l|l|}
\hline & Frequency & Percent & $\begin{array}{l}\text { Valid } \\
\text { Percent }\end{array}$ & $\begin{array}{l}\text { Cumulative } \\
\text { Percent }\end{array}$ \\
\hline Male & 58 & 79.5 & 79.5 & 79.5 \\
\hline Female & 15 & 20.5 & 20.5 & 100.0 \\
\hline Total & 73 & 100.0 & 100.0 & \\
\hline
\end{tabular}

Table 2. Demographic variable-Age

\begin{tabular}{|l|l|l|l|l|}
\hline & $\begin{array}{l}\text { Frequenc } \\
\mathrm{y}\end{array}$ & Percent & $\begin{array}{l}\text { Valid } \\
\text { Percent }\end{array}$ & $\begin{array}{l}\text { Cumulative } \\
\text { Percent }\end{array}$ \\
\hline $20-30$ & 49 & 67.1 & 67.1 & 67.1 \\
\hline $31-40$ & 15 & 20.5 & 20.5 & 87.7 \\
\hline $\begin{array}{l}\text { above } \\
50\end{array}$ & 9 & 12.3 & 12.3 & 100.0 \\
\hline Total & 73 & 100.0 & 100.0 & \\
\hline
\end{tabular}

(Tables 4 - 6).

From the table 4 we can say that there is a positive correlation of 0.492 between the internal locus of control and job satisfaction level which is significant at the 0.01 level i.e. the probability of this not being true is $1 \%$ or less. That is over, $99 \%$ of the time we would expect this correlation to exist.

From the table 5 we can say that there is a correlation of 0.147 between the external (others) locus of control and job satisfaction level but it is not significant at the 0.01 level because the value of significance is 0.213 which is higher then 0.01 .

From the table 6 we can see that there is a partially positive correlation between External (Chance) locus of control and job satisfaction level of employees. And it is not even significant at the 0.01 level because the value of significance is 0.993 which is quite higher then 0.01 .

\subsubsection{One-Way ANOVA}

One-way ANOVA table is a statistical tool which helps us to know the degree of variance between one factor and other variables. It helps us to know how the main factor will get influenced by other variables. Mostly One-way ANOVA is used to measure how different demographical variables will have an impact on particular variable. Results are presented in Tables 7 - 9 .

Table 3. Demographic variable-Education

\begin{tabular}{|l|l|l|l|l|}
\hline & $\begin{array}{l}\text { Frequen } \\
\text { cy }\end{array}$ & $\begin{array}{l}\text { Perce } \\
\text { nt }\end{array}$ & $\begin{array}{l}\text { Valid } \\
\text { Perce } \\
\text { nt }\end{array}$ & $\begin{array}{l}\text { Cumula } \\
\text { tive } \\
\text { Percent }\end{array}$ \\
\hline post graduate & 19 & 26.0 & 26.0 & 26.0 \\
\hline graduate & 41 & 56.2 & 56.2 & 82.2 \\
\hline $\begin{array}{l}\text { diploma/certif } \\
\text { icate }\end{array}$ & 12 & 16.4 & 16.4 & 98.6 \\
\hline doctorate & 1 & 1.4 & 1.4 & 100.0 \\
\hline Total & 73 & 100.0 & 100.0 & \\
\hline
\end{tabular}


I One-Way ANOVA showing the relationship between demographic factors with internal locus of control.

Gender: If we take 0.90 as a level of significance we can say that there is no significant variance between gender and internality because value of sig. is 0.378 which is more than 0.10 .

Age: If we take 0.90 as a level of significance we can say that there is a significant variance between age and internality because value of sig. is 0.079 which is lesser than 0.10 . It means there is a significant variance among the different age groups when they are asked about internality.

Education: There is no significant variance between education and internality because value of sig. is 0.983 which is more than 0.10 which means different education groups have the same opinion when they are asked about internal locus of control.

II One-Way ANOVA showing relationship between demographic factors with External (others) locus of control.

Gender: If we take 0.90 as a level of significance we can say that there is no significant variance between gender and Externality (Others) locus of Control because value of sig. is 0.463 which is more than 0.10 .

Table 4. Correlation between Internality \& Job Satisfaction

\begin{tabular}{|c|c|c|}
\hline & Internality & Job satisfaction \\
\hline $\begin{array}{ll}\text { Internality } & \text { Pearson } \\
\text { Correlation } & \end{array}$ & 1 & $.492(* *)$ \\
\hline Sig. (2-tailed) & & .000 \\
\hline \multirow{4}{*}{\begin{tabular}{l} 
Job \\
Correlation \\
satisfaction Sig. (2-tailed) \\
\multicolumn{2}{c}{ N }
\end{tabular}} & 73 & 73 \\
\hline & $.492(* *)$ & 1 \\
\hline & .000 & \\
\hline & 73 & 73 \\
\hline
\end{tabular}

Table 5. Correlation between Externality (Other) \& Job Satisfaction

\begin{tabular}{|ll|r|r|}
\hline & \multicolumn{1}{|c|}{$\begin{array}{c}\text { Job } \\
\text { satisfaction }\end{array}$} & Externality Others \\
\hline Job & Pearson Correlation & 1 & .147 \\
\cline { 3 - 4 } satisfaction & Sig. (2-tailed) & & .213 \\
\cline { 3 - 3 } Externality & Pearson Correlation & 73 & 73 \\
\cline { 3 - 4 } Others & Sig. (2-tailed) & .147 & 1 \\
\cline { 3 - 4 } & $\mathrm{N}$ & .213 & \\
\cline { 3 - 4 } & & 73 & 73 \\
\cline { 3 - 4 } & & & \\
\cline { 3 - 4 } & &
\end{tabular}

Age: If we take 0.90 as a level of significance we can say that there is no significant variance between age and Externality (Others) locus of Control because value of sig. is 0.933 which is more than 0.10 .

Education: If we take 0.90 as a level of significance we can say that there is no significant variance between education and Externality (Others) locus of Control because value of sig. is 0.564 which is more than 0.10 .

III One-Way ANOVA showing relationship between demographic factors with External (chance) locus of control.

Gender: If we take 0.90 as a level of significance we can say that there is no significant variance between gender and Externality (Chance) locus of Control because value of sig. is 0.398 which is more than 0.10 .

Table 6. Correlation between Externality (Chance) \& Job Satisfaction

\begin{tabular}{|c|c|c|}
\hline & $\begin{array}{c}\text { Job } \\
\text { satisfaction }\end{array}$ & Externality Chance \\
\hline \multirow{6}{*}{$\begin{array}{ll}\text { Job } & \text { Pearson Correlation } \\
\text { satisfaction } & \text { Sig. (2-tailed) } \\
& \mathrm{N} \\
\text { Externality } & \text { Pearson Correlation } \\
\text { chance } & \text { Sig. (2-tailed) } \\
& \mathrm{N}\end{array}$} & 1 & .001 \\
\hline & & .993 \\
\hline & 73 & 73 \\
\hline & .001 & 1 \\
\hline & .993 & \\
\hline & 73 & 73 \\
\hline
\end{tabular}


Age: If we take 0.90 as a level of significance we can say that there is a significant variance between age and Externality (Chance) locus of Control because value of sig. is 0.025 which is lesser than 0.10. It means there is a significant variance among the different age groups when they are asked about Externality (chance).

Education: If we take 0.90 as a level of significance we can say that there is no significant variance between education and Externality (Chance) locus of Control because value of sig. is 0.205 which is more than 0.10 .

\section{CONCLUSION}

The Researcher found that there exists more of internal locus of control among the employees of public sectors in Bangalore. (As per Ratio Analysis)

The researchers were able to identify that internal locus of control has significantly positive impact on job satisfaction of employees. While in case of external locus of control there is a positive relation between externality (others) \& externality (chance) and job satisfaction level of employees but it is not significant.

Judge, Timothy A.; Bono, Joyce E (2001) found that there is a positive correlation (of 0.32) between internal locus of control and job satisfaction. In this research also authors were able to find that there is a positive correlation (of 0.49) between internal locus of control and job satisfaction. (As per Correlation Analysis).

Bachrach \& Peterson (1976) \& Lefcourt (1982) says that the development of locus of control is hypothesized to progress from a more external locus of control to a more internal locus of control as one matures. Same way here researcher have found that there exists significant variance between age of Employees and internal locus of control with the value of significance as 0.01 (As per One-way ANOVA).

Sandstrom \& Coie (1999) says that External locus of control is correlated with peer rejection. Oesterman et al (1999) says

Table 7. One-Way ANOVA showing relationship between demographic factors and internal locus of control

\begin{tabular}{|l|l|r|r|r|r|r|}
\hline \multicolumn{2}{|l|}{ Demographic Variables } & $\begin{array}{c}\text { Sum of } \\
\text { Squares }\end{array}$ & \multicolumn{1}{c|}{$\mathrm{df}$} & \multicolumn{1}{c|}{$\begin{array}{c}\text { Mean } \\
\text { Square }\end{array}$} & \multicolumn{1}{c|}{ F } & \multicolumn{1}{c|}{ Sig. } \\
\hline Gender & $\begin{array}{l}\text { Between } \\
\text { Groups }\end{array}$ & 3.543 & 20 & .177 & 1.100 & .378 \\
\hline & Within Groups & 8.375 & 52 & .161 & & \\
\hline Age & Total & 11.918 & 72 & & & \\
\hline & $\begin{array}{l}\text { Between } \\
\text { Groups }\end{array}$ & 27.737 & 20 & 1.387 & 1.635 & .079 \\
\hline & Within Groups & 44.099 & 52 & .848 & & \\
\hline Education & Total & 71.836 & 72 & & & \\
\hline & $\begin{array}{l}\text { Between } \\
\text { Groups }\end{array}$ & 119.263 & 20 & 5.963 & .416 & .983 \\
\hline & Within Groups & 746.107 & 52 & 14.348 & & \\
\hline & Total & 865.370 & 72 & & & \\
\hline
\end{tabular}


Table 8. One-Way ANOVA showing relationship between demographic factors and External (others) locus of control

\begin{tabular}{|l|l|r|r|r|r|r|}
\hline $\begin{array}{l}\text { Demographi } \\
\text { c Variables }\end{array}$ & $\begin{array}{c}\text { Sum of } \\
\text { Squares }\end{array}$ & \multicolumn{1}{c|}{ df } & \multicolumn{1}{c|}{$\begin{array}{c}\text { Mean } \\
\text { Square }\end{array}$} & \multicolumn{1}{c|}{ F } & Sig. \\
\hline \multirow{3}{*}{ Gender } & $\begin{array}{l}\text { Between } \\
\text { Groups }\end{array}$ & 3.174 & 19 & .167 & 1.013 & .463 \\
\cline { 2 - 7 } & Within Groups & 8.744 & 53 & .165 & & \\
\cline { 2 - 7 } & Total & 11.918 & 72 & & & \\
\hline \multirow{3}{*}{ Age } & $\begin{array}{l}\text { Between } \\
\text { Groups }\end{array}$ & 11.555 & 19 & .608 & .535 & .933 \\
\cline { 2 - 8 } & Within Groups & 60.280 & 53 & 1.137 & & \\
\cline { 2 - 8 } & Total & 71.836 & 72 & & & .564 \\
& $\begin{array}{l}\text { Between } \\
\text { Groups }\end{array}$ & 214.326 & 19 & 11.280 & .918 & \\
\cline { 2 - 8 } & Within Groups & 651.044 & 53 & 12.284 & & \\
\cline { 2 - 8 } & Total & 865.370 & 72 & & & \\
\hline
\end{tabular}

Table 9. One-Way ANOVA showing relationship between demographic factors and External (Chance) locus of control

\begin{tabular}{|l|l|r|r|r|r|r|}
\hline $\begin{array}{l}\text { Demographic } \\
\text { Variables }\end{array}$ & $\begin{array}{c}\text { Sum of } \\
\text { Squares }\end{array}$ & \multicolumn{1}{c|}{ df } & \multicolumn{1}{c|}{$\begin{array}{c}\text { Mean } \\
\text { Square }\end{array}$} & \multicolumn{1}{c|}{ F } & \multicolumn{1}{c|}{ Sig. } \\
\hline \multirow{7}{*}{ Gender } & $\begin{array}{l}\text { Between } \\
\text { Groups }\end{array}$ & 3.667 & 21 & .175 & 1.079 & .398 \\
\cline { 2 - 7 } & Within Groups & 8.251 & 51 & .162 & & \\
\cline { 2 - 7 } Age & Total & 11.918 & 72 & & & \\
& $\begin{array}{l}\text { Between } \\
\text { Groups }\end{array}$ & 32.175 & 21 & 1.532 & 1.970 & .025 \\
\cline { 2 - 7 } & Within Groups & 39.661 & 51 & .778 & & \\
\cline { 2 - 7 } & Total & 71.836 & 72 & & & \\
\hline \multirow{2}{*}{ Education } & $\begin{array}{l}\text { Between } \\
\text { Groups }\end{array}$ & 305.178 & 21 & 14.532 & 1.323 & .205 \\
\cline { 2 - 8 } & Within Groups & 560.192 & 51 & 10.984 & & \\
\cline { 2 - 7 } & Total & 865.370 & 72 & & & \\
\hline
\end{tabular}

that External locus of control is correlated with aggression. And all these negative attributes will lead to job dissatisfaction. Here also researcher have found that external locus of control lead to job dissatisfaction as correlation of both external (others) \& external (chance) with job satisfaction are not at all significant. 


\title{
ПОЛОЖАЈ КОНТРОЛЕ И ЗАДОВОЉСТВО ПОСЛОМ ЗАПОШЉЕНИХ У ЈАВНОМ СЕКТОРУ
}

\author{
Lakshman Vijayashree $^{\mathbf{a}^{*}}$ and Mali Vishalkumar Jagdischchandrab \\ $a_{\text {PES School of Engineering, }}$ \\ Hosur Road, Bangalore- 100, India

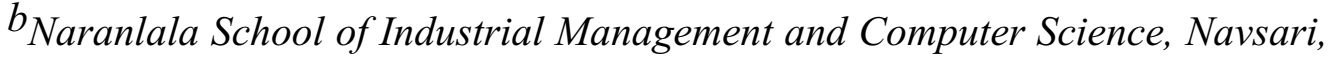 \\ Bhagwati Sankul, Near Eru Char Rasta, Navsari-396450, Gujarat, India
}

\section{Извод}

Претходна истраживања су показала да разлика у положају контроле (интерни или екстерни), у многоме утиче на задовољство послом. Ова студија ће бити од велике помоћи организацијама у смислу разумевања типа контроле који над својим запосленима имају и како то утиче на њихово задовољство послом.

Циљеви студије су били: 1- Идентификовати тип положаја контроле (Интерни или Екстерни), који је присутан у јавним предузећима у Бангалору (Индија) и 2- Анализа утицаја различитих типова контроле на запошљене. У току испитивања, узети су у обзир и различити демографски показатељи испитанике. Као алат коришћена је методологија "Loco Inventory", коју је развио Левенсон 1972. године. Истраживање се заснива на коришћењу упитника. Од статистичких техника анализе резултата употребљени су АНОВА и корелациона анализа.

Истраживања показују да постоји позитивна корелација, како интерне тако и екстерне позиције контроле у разматраним предузећима, са задовољством запослених. Такође установљено је постојање утицаја старости испитаника на варијансу екстерне и интерне позиције контроле. Пол, и ниво образовања немају статистички значајан утицај.

Кључне речи: Интерни - екстерни положај контеоле, Задовољство послом, "Loco Inventory"

\section{References}

Boone, C., De Brabander, B., \& Hellemans, J. (2000). CEO locus of control and small firm performance. Organization Studies, 21(3): 641-646.

Brown, S., \& Peterson, R. (1993). Antecedents and Consequences of Salesperson Job Satisfaction: Meta Analysis and Assessment of Casual Effects. Journal of Marketing Research, 30: 63-77.

Flytzani, S., \& Nijkamp, P. (2008). Locus of Control and Cross-Cultural Adjustment of Expatriate Managers. International Journal of Foresight and Innovation Policy, 4(1-2): 146-159.

Freeman, R.B. (1978). Job Satisfaction as an Economic Variable. American Economic Review, 68(2): 135-141.

Hsul, H. (2006). The relationship among culinary arts workers locus of control, demographic variables, job satisfaction, work stress, and turnover intention. Journal of Foodservice of Business Research, 9(2/3): 151-168.

Hyatt, T.A., \& Prawitt, D.F. (2001). Does Congruence between Audit Structure and Auditors' Locus of Control Affect Job 
Performance. The Accounting Review, 76(2): 263-274.

Inegbenebor, A.U. (2007). Pharmacists as Entrepreneurs or Employees: The Role of Locus of Control. Tropical Journal of Pharmaceutical Research, 6(3): 747-754.

Judge, T.A., \& Bono, J.E. (2001). Relationship of core self-evaluations traitsself-esteem, generalized self-efficacy, locus of control, and emotional stability - with job satisfaction and job performance: A metaanalysis. Journal of Applied Psychology, 86(1): 80-92.

Judge, T.A., Heller, D. \& Mount, M.K. (2002). Five Factor Model of Personality and Job Satisfaction- A Meta Analysis. Journal of Applied Psychology, 87(3): 530541.

Julian B. Rotter. (1954) Development of Locus of Control. In Pareek Training Instruments in HRD and OD.

Kuye, O., L., \& Sulaimon, A.H.A. (2011) Employee involvement in decision making and firms performance in the manufacturing sector in Nigeria. Serbian Journal of Management, 6(1): 1-15.

Levenson (1972). Loco Inventory. In Udai Pareek (Eds), Training Instruments in HRD and OD. Tata McGraw hill.

Linz, S.J. (2003). Job Satisfaction Among Russian Workers. International Journal of Manpower, 24(6): 626-652.

Linz, S.J. (2009). Job Satisfaction - A Comparative Analysis - Global Edge Business Review, 3(6): 1-3.

Locke, E A (1976). The nature and causes of job satisfaction, Handbook of Industrial and organizational Psychology, Chicago, rand and McNally.

Morris, J., \& Sherman, J. D. (1981). Generalizability of an organizational commitment model. Journal of Vocational Behaviour, 24: 512-526.
Murray, R.A. (1999). Job Satisfaction of Professional and Paraprofessional Library Staff at the University of North Carolina at Chapel Hill. February, Dissertation. 1999. 56 pages. Advisor: Robert M. Losee.

Nerison, H.A. (1999). A Descriptive study of Job Satisfaction among vocational Rehabilitation Counsellors in a Midwestern State, A Research paper for Master of Science, University of Wisconsin-Stout.

Rani, S., \& Selvarani, K. (2011). Work/Life balance reflections on employee satisfaction. Serbian Journal of Management, 6(1): 85-96.

Salazar, J., Hubbard, S., Salazar, L. (2002). Locus of Control and Its Influence on Hotel Managers' Job Satisfaction. Journal of Human Resources in Hospitality \& Tourism, 1(2): 15-26.

Suwarsi, S., \& Budianti, N. (2009). Influence of Locus of Control and Job Involvement to Organizational Culture Applied By Employees on Bank X. World Academy of Science, Engineering and Technology, 60: 616-621.

Wijbenga, F.H. \& van Witteloostuijn, A. (2007). Entrepreneurial locus of control and competitive strategies - The moderating effect of environmental dynamism. Journal of Economic Psychology, 28(5): 566-589. 